ISSN 2083-3725
Authors' contribution/

Wkład autorów:

A. Zaplanowanie badań/

Study design

B. Zebranie danych/

Data collection

C. Analiza statystyczna/

Statistical analysis

Data interpretation

E. Przygotowanie tekstu/

Manuscript preparation

F. Opracowanie

piśmiennictwa/

Literature search

G. Pozyskanie funduszy/

Funds collection
D. Interpretacja danych/

\section{INTEGRATED TERRITORIAL INVESTMENTS IN THE FORMULA OF COHESION POLICY 2014 - 2020}

\author{
ZINTEGROWANE INWESTYCJE TERYTORIALNE \\ W FORMULE POLITYKI SPÓJNOŚCI 2014 - 2020
}

\author{
Iwona Kowalska
}

Warsaw University of Life Sciences

Szkoła Główna Gospodarstwa Wiejskiego w Warszawie

Kowalska I. (2017), Integrated territorial investments in the formula of cohesion policy 2014 - 2020/Zintegrowane inwestycje terytorialne w formule polityki spójności 2014 - 2020. Economic and Regional Studies. Vol. 10, No. 1, pp. 36-50. https://doi.org/10.2478/ers-2017-0003

\section{Summary}

\section{ORIGINAL ARTICLE}

JEL code: G2,H7,01

Submitted:

January 2017

Accepted:

March: 2017

Tables: 4

Figures: 0

References: 31

ORYGINALNY ARTYKUŁ NAUKOWY

Klasyfikacja JEL: G2,H7,01

Zgłoszony:

styczeń 2017

Zaakceptowany:

marzec 2017

Tabele: 4

Rysunki: 0

Literatura: 31
Subject and purpose of work: EU regional policy aims to increase the economic and social cohesion of the Member States. For the programming period of 2014 - 2020 a new tool has been planned, which will contribute to the effective implementation of the cohesion policy - Integrated Territorial Investment (ITI). The aim of this article is to determine whether the direction of measures arising from the assumptions of the cohesion policy 2014 - 2020, implemented in the ITI strategy, addresses actual problems in the area covered by the ITI strategy (on the example of Kalisz-Ostrów Agglomeration - KOA). Materials and methods: The study was based on the analysis and synthesis of EU and Polish regulatory provisions on the cohesion policy 2014 - 2020, data on financial allocation for the implementation of the ITI and literature on the subject of EU regional policy.

Results: The direction of measures arising from the assumptions of the cohesion policy 2014 - 2020 in the ITI strategy addresses real problems in the development of the area covered by the KOA strategy. EU funds have been planned for: promoting entrepreneurship; promoting low-carbon strategies; the development of an educated society and investments in modern infrastructure.

Conclusions: Solving the problems of the areas covered by the ITI strategy will depend on the realization of the development goals. Therefore, the synergy of conditions associated with the transformation of the postulated stage into the executive stage of the cohesion policy under ITI is necessary. This synergy is associated with both the quality of human capital and the amount of financial resources as well as the competences of those involved in the implementation of the ITI concept.

Keywords: EU, finance, cohesion policy, ITI, KOA

\section{Streszczenie}

Przedmiot i cel pracy: Polityka regionalna Unii Europejskiej ma na celu zwiększenie spójności ekonomicznej i społecznej krajów członkowskich. W okresie programowania 2014 - 2020 zaplanowano nowe narzędzie, które ma przyczynić się do skutecznego wdrażania polityki spójności - Zintegrowane Inwestycje Terytorialne (ZIT). Celem artykułu jest ustalenie czy kierunek działań wynikających z założeń polityki spójności 2014 - 2020 implementowanych w strategii ZIT odpowiada na rzeczywiste problemy rozwoju obszaru objętego strategią ZIT (na przykładzie Aglomeracji Kalisko-Ostrowskiej - AKO). Materiały i metody: Praca została wykonana na podstawie analizy i syntezy unijnych jak i polskich zapisów regulacyjnych dotyczących polityki spójności 2014 - 2020, danych dotyczących alokacji finansowej na realizację ZIT oraz literatury przedmiotu dotyczącej polityki regionalnej UE.

Wyniki: Kierunek działań wynikających z założeń polityki spójności 2014 - 2020 w strategii ZIT odpowiada na rzeczywiste problemy rozwoju obszaru objętego strategią AKO. Środki unijne zostały zaplanowane na: wspieranie przedsiębiorczości; promocję strategii niskoemisyjnych; rozwój wykształconego społeczeństwa oraz inwestycje w nowoczesną infrastrukturę.

Wnioski: Rozwiązywanie problemów obszarów objętych strategią ZIT zależeć będzie od wykonania celów rozwojowych. Konieczna jest zatem synergia uwarunkowań związanych z przekształceniem stanu postulatywnego w stan wykonawczy polityki spójności w ramach ZIT. Synergia ta dotyczy zarówno jakości kapitału ludzkiego jak i wysokości zasobów finansowych oraz kompetencji podmiotów zaangażowanych w realizację koncepcji ZIT.

Słowa kluczowe: UE, finanse, polityka, spójność, ZIT, AKO

\footnotetext{
Address for correspondence/ Adres korespondencyjny: dr hab. Iwona Kowalska, prof. SGGW, Szkoła Główna Gospodarstwa Wiejskiego w Warszawie, ul. Nowoursynowska 166, 02-787 Warszawa, Polska; tel.: +48 6021509 71, mail: iwona_kowalska@sggw.pl

Journal indexed in/ Czasopismo indeksowane w: AgEcon Search, AGRO, BazEkon, Index Copernicus Journal Master List, ICV 2015: 81,26; Polish Ministry of Science and Higher Education 2016: 9 points/ AgEcon Search, AGRO, BazEkon, Index Copernicus Journal Master List ICV 2015: 81,26; Ministerstwie Nauki i Szkolnictwa Wyższego 2016: 9 punktów. Copyright: (C) 2016 Pope John Paul II State School of Higher Education in Biała Podlaska, Iwona Kowalska. All articles are distributed under the terms of the Creative Commons Attribution-NonCommercial-ShareAlike 4.0 International (CC BY-NC-SA 4.0) License (http://creativecommons.org/licenses/by-nc-sa/4.0/), allowing third parties to copy and redistribute the material in any medium or format and to remix, transform, and build upon the material, provided the original work is properly cited and states its license.
} 


\section{Introduction}

Cohesion policy in the financial programming for 2014-2020 is focused on financing interventions adjusted to specific types of territories. This example of a change in the approach to the method of funding aims to utilize the funds more effectively compared to the previously used traditional interventions. The territorial approach which assumes a departure from perceiving an area through the prism of administrative boundaries, takes into account internal potentials, challenges and obstacles to development. (MIiR 2015, p. 4). Integrated Territorial Investments (ITI) will be a tool intended to improve the effectiveness of the cohesion policy implementation. This instrument will be implemented in fourteen EU countries: Belgium, Germany, Greece, Spain, Finland, France, Italy, Lithuania, Portugal, Romania, Sweden, Slovakia, Great Britain and Poland (Dawydzik 2015, p. 4). In Poland, the work on the conceptualisation of the ITI strategy was completed in 2016. Therefore, it is possible to attempt a preliminary analysis of the investment directions within the ITI strategy. The aim of this article is to determine whether the direction of measures arising from the assumptions of the cohesion policy $2014-2020$, implemented in the ITI strategy, addresses actual problems in the development of the area covered by the ITI strategy (for example Kalisz-Ostrów Agglomeration - KOA). The choice of KOA ITI was due to the fact that it is an example of a diversified structure, which includes not only various functional types of communes (urban, rural and urban - rural), but also counties (Kalisz, Ostrów and Pleszew). Moreover, KOA ITI is a good example of an emerging zone in which two cities: Kalisz and Ostrów Wielkopolski impact their environment (including rural communes). It was assumed as a hypothesis that the direction of measures resulting from the assumptions of the 2014-2020 cohesion policy, implemented within ITI strategy, addresses real development issues of the area covered by the KOA strategy. The method applied in this study was the analysis of the documents, using data from both the EU and Polish regulations and the literature on regional policy in the EU programming for 2014-2020.

\section{The Cohesion Policy 2014 - 2020 and the Integrated Territorial Investments}

The experience from previous periods of implementing cohesion policy pointed to, among others, the difficulty in identifying a clear impact of this policy on socio - economic development through measurable indicators ${ }^{1}$. Therefore, the current reform

\footnotetext{
${ }^{1}$ The analyses of the effects of cohesion policy have been the subject of work undertaken by independent bodies (De Dominicis 2014, Ederveen i in. 2006, Rodriguez-Pose and Fratesi 2004), bu also by the EU. Reference can be made to the following reports: Sapir Hübner, Samecki, Barka. Evaluation of the cohesion policy effects is also presented in national publications (e.g. Boni 2009; Boni 2013; Geodecki et al. 2012; Gorzelak 2007 and 2014; Olbrycht et al. 2013, Misiąg et al. 2013).
}

\section{Wstęp}

Polityka spójności w programowaniu finansowym 2014-2020 jest skoncentrowana na finansowaniu interwencji dostosowanych do określonych typów terytoriów. Ten przykład zmiany w podejściu do sposobu finansowania ma służyć bardziej efektywnemu wykorzystaniu środków funduszowych $\mathrm{w}$ porównaniu $\mathrm{z}$ dotychczas stosowanymi interwencjami tradycyjnymi. Podejście terytorialne zakładające odejście od postrzegania obszaru przez pryzmat administracyjnych granic, bierze pod uwagę wewnętrzne potencjały, wyzwania i bariery rozwojowe (MIiR 2015, s. 4). Zintegrowane Inwestycje Terytorialne (ZIT) mają być tym narzędziem który ma przyczynić się do zwiększenia efektywności realizacji polityki spójności. Instrument ten będzie realizowany w czternastu państwach UE: w Belgii, Niemczech, Grecji, Hiszpanii, Finlandii, Francji, Włoszech, Litwie, Portugalii, Rumunii, Szwecji, Słowacji, Wielkiej Brytanii oraz w Polsce (Dawydzik 2015, s. 4). W Polsce prace nad koncepcjami strategii ZIT zostały zakończone w roku 2016. Można zatem podjąć się próby wstępnej analizy kierunków inwestycji w ramach strategii ZIT. Celem artykułu uczyniono zatem ustalenie czy kierunek działań wynikających z założeń polityki spójności 2014 - 2020 implementowanych w strategii ZIT odpowiada na rzeczywiste problemy rozwoju obszaru objętego strategią ZIT (na przykładzie Aglomeracji Kalisko-Ostrowskiej - AKO). Wybór ZIT AKO wynikał z faktu, iż jest to przykład zróżnicowanej struktury obejmującej nie tylko różne typy funkcjonalne gmin (miejskie, wiejskie i miejsko - wiejskie), ale także powiaty (kaliski, ostrowski i pleszewski). Ponadto ZIT AKO jest dobrym przykładem wyodrębniającej się strefy oddziaływania dwóch miast: Kalisza i Ostrowa Wielkopolskiego na otoczenie (w tym gmin wiejskich). Przyjęto hipotezę, iż kierunek działań wynikających z założeń polityki spójności 2014 - 2020 implementowanych w strategii ZIT odpowiada na rzeczywiste problemy rozwoju obszaru objętego strategią AKO. W pracy zastosowano metodę analizy dokumentów z wykorzystaniem danych pochodzących zarówno z unijnych jak i polskich zapisów regulacyjnych oraz literatury przedmiotu dotyczacej polityki regionalnej w programowaniu unijnym 2014 - 2020.

\section{Polityka spójności 2014 - 2020 a Zintegrowane Inwestycje Terytorialne}

Doświadczenia z wcześniejszych okresów realizacji polityki spójności wskazywały m.in. na trudności z określeniem wyraźnego wpływu tej polityki na rozwój społeczno - gospodarczy poprzez mierzalne wskaźniki ${ }^{1}$. Dlatego też aktualna reforma polityk

\footnotetext{
${ }^{1}$ Analizy efektów polityki spójności były przedmiotem prac po-
dejmowanych przez niezależne gremia (De Dominicis 2014; Ederveen i in. 2006, Rodriguez-Pose i Fratesi 2004), ale także przez UE. Można tu wymienić raporty: Sapira Hűbner, Sameckiego, Barki. Ocena efektów polityki spójności jest także prezentowana w opracowaniach krajowych (np. Boni 2009; Boni 2013; Geodecki i inni 2012; Gorzelak 2007 i 2014; Olbrycht i in. 2013, Misiąg i in. 2013).
} 
of the policies co-financed by the European Union budget is based on the idea of improved coordination of EU and national policies and strengthening the interdependence between the selected areas of public intervention. The main directions of the reform involve:

1. functional integration of numerous areas of public policy in order to realize the common objectives of the Europe 2020 strategy;

2. departing from the logic of the demarcation line to the logic of joint solutions;

3. introducing new mechanisms contributing to the concentration of interventions;

4. stricter rules for achieving results (conditionality, performance reserve, suspension / cancellation of funding);

5. stricter disciplines of institutional capacity (ex-ante conditionality, accreditation).

Territorial cohesion is a new and important dimension of cohesion policy (CP) after 2013. The experiences in implementing cohesion policy till 2013 showed that the realization of interventionsintegrated both territorially and thematically is advisable, as the main goal of EU regional policy is to increase the economic and social cohesion of the Member States. The assistance provided to the less developed regions and economy sectors in the Member States is an effort to reduce the differences in development levels and living standards of the EU regions. Investments in the regional policy allow for reducing the disparities in development between the poorest and the richest regions. The financial assistance provided towards this end is intended to overcome the differences among countries and develop a closer integration within the EU (Wiśniewska 2014, p. 31). Regional aid can be considered effective when it is focused on the least privileged regions and when the benefits from applying such aid outweigh the potential disturbance in competition which results from it.

In the light of the above discussion concerning the assumptions of the cohesion policy, it is a noteworthy fact that the issue of enhancing the urban dimension in CP after 2013 is more clearly emphasised. This approach is manifested, among others, in:

1. The Declaration of the Ministers of EU Member States in Toledo on the role of cities in the Europe 2020 Strategy;

2. V Cohesion Report, in which the role of cities and functional approach was highlighted;

3. analysis of the role of cities in the context of demographic challenges and climate change conducted by Hungarian Presidency of the EU Council,

4. the report on cities in CP prepared during Polish Presidency,

5. The European Commission produced a report: Cities of tomorrow.

Cities are identified as the main centres of the development of regions which, thanks to diffusion and functional integration with the surrounding areas, will ensure an increase in the development opportunities for residents of rural areas and smaller towns located in their vicinity. Cities are supposed współfinansowanych z budżetu Unii Europejskiej oparta jest na założeniu ściślejszej koordynacji polityk unijnych z krajowymi oraz wzmacnianiu współzależności wybranych dziedzin interwencji publicznej. Główne kierunki reformy dotyczą m.in.:

1. funkcjonalnej integracji wielu dziedzin polityki publicznej dla realizacji wspólnych celów wynikających ze strategii Europa 2020;

2. odejście od logiki linii demarkacyjnej na rzecz logiki wspólnych rozwiązań;

3. wprowadzenie nowych mechanizmów na rzecz koncentracji interwencji;

4. zaostrzenie rygorów dotyczących osiagania wyników (warunkowość, rezerwa wykonania, wstrzymanie/ anulowanie środków);

5. zaostrzenie rygorów dotyczących zdolności instytucjonalnych (warunkowość ex-ante, akredytacja).

Spójność terytorialna jest nowym, istotnym wymiarem polityki spójności (PS) po 2013 r. Doświadczenia związane $\mathrm{z}$ wdrażaniem polityki spójności do 2013 r. pokazały, że wskazana byłaby realizacja interwencji zintegrowanych zarówno obszarowo jak i tematycznie. Głównym bowiem celem polityki regionalnej Unii Europejskiej jest zwiększanie spójności ekonomicznej i społecznej państw członkowskich. Poprzez pomoc słabiej rozwiniętym regionom i sektorom gospodarek państw członkowskich dąży się do zmniejszenia różnic w poziomie rozwoju i w poziomie życia w regionach UE. Wydatki na politykę regionalną umożliwiają zmniejszenie różnic rozwojowych występujących między regionami najbiedniejszymi a najbogatszymi. Pomoc finansowa udzielana w tym zakresie ma na celu pokonanie różnic między krajami oraz zacieśnienie integracji w obrębie UE (Wiśniewska 2014, s. 31). Pomoc regionalną można uznać za skuteczną, gdy skupia się na regionach najmniej uprzywilejowanych i gdy korzyści ze stosowania tej pomocy przeważają nad wynikającymi z jej stosowania ewentualnymi zakłóceniami konkurencji .

Na tle powyższej dyskusji o założeniach polityki spójności na uwagę zasługuje fakt, iż wyraziście wybrzmiewa kwestia wzmocnienia wymiaru miejskiego w PS po 2013 roku. Wyraz tego podejścia uwidoczniony jest m.in. w:

1. deklaracji z Toledo Ministrów państw członkowskich UE dotyczący roli miast w Strategii Europa 2020;

2. V Raporcie Kohezyjnym podkreślono rolę miast i podejścia funkcjonalnego;

3. prezydencji węgierskiej Rady UE analizowano rolę miast w kontekście wyzwań demograficznych oraz zmiany klimatycznych,

4. podczas prezydencji polskiej przygotowano raport nt. miast w PS,

5. KE opracowała raport: Cities of tomorrow.

Miasta są identyfikowane jako główne ośrodki rozwoju regionów, które dzięki dyfuzji i integracji funkcjonalnej $\mathrm{z}$ otaczającymi obszarami zapewnią zwiększenie możliwości rozwojowych mieszkańcom obszarów wiejskich i mniejszych miast położonych w ich pobliżu. Miasta mają pełnić funkcje rdzeni ZIT - 
to function as cores of ITI - a new instrument for the implementation of the regional operational program (ROP) for cohesion policy 2014-2020.

\section{Integrated Territorial Investments - main assumptions}

Integrated Territorial Investments form a new instrument proposed by the European Commission (EC) in order to implement integrated interventions not only territorially, but also thematically. The development and use of this tool is intended to support the implementation of projects being thematically diverse, but at the same time complementary and interrelated with one another. The main goals of ITI implementation include:

- strengthening an integrated territorial approach,

- supporting local development through the implementation of the most important investments,

- more accurate adjustment of aid from the European Union in relation to the needs and potentials of particular types of regions in Poland (Gwizda et al. 2014, p. 99).

With such delineated area of ITI objectives realisation the legal basis for their operation are regulated at the level of both EU and national legislation. The summary of the legal basis for the functioning of ITI in Poland is presented in Table 1.

The implementation of the Integrated Territorial Investment instrument is possible under the following conditions:

1. Establishment of institutionalized forms of partnership (establishment of the ITI Association/ ITI Partnership). ITI associations will serve as a joint representation for the authorities of communes and areas having functional links with them, when dealing with the national and regional government.

2. Preparation of the ITI Strategy - the basic document regarding the provision of aid from measures/priorities implemented in the formula of ITI under ROP.

3. Possession of appropriate institutional capacity - in the institutional system the established RPO partnerships act as Intermediary Institutions (IP ITI).

4. The signing of the agreement for the implementation of ITI in a province between an ITI Association/ITI Agreement and the ROP Managing Authority.

5. Inclusion of appropriate provisions in the ROP, fulfilling the requirements of the EC and in accordance with the provisions of the Partnership Agreement (MIiR 2015, p. 11).

Integrated Territorial Investments will be mainly implemented in provincial cities and areas associated with them functionally within the ROP. As defined in the National Spatial Development Concept 2030, an urban functional area (UFA) is a spatially continuous settlement system, which is composed of separate administrative units. It includes a dense urban area, nowego instrumentu realizacji regionalnych programów operacyjnych (RPO) w polityce spójności 20142020.

\section{Zintegrowane Inwestycje Terytorialne - główne założenia}

Zintegrowane Inwestycje Terytorialne są nowym narzędziem zaproponowanym przez Komisję Europejską (KE) w celu realizacji interwencji zintegrowanych nie tylko obszarowo, ale również tematycznie. Opracowanie i wykorzystanie tego narzędzia ma na celu wsparcie realizacji projektów zróżnicowanych tematycznie, lecz jednocześnie komplementarnych i powiązanych ze sobą. Do głównych celów realizacji ZIT zalicza się:

- wzmocnienie zintegrowanego podejścia terytorialnego,

- wsparcie lokalnego rozwoju dzięki realizacji najistotniejszych inwestycji,

- bardziej dokładne dopasowanie środków pomocowych z Unii Europejskiej w odniesieniu do potrzeb oraz potencjałów poszczególnych typów regionów w Polsce (Gwizda i in. 2014, s. 99).

Przy tak zarysowanym obszarze realizacji celów ZIT podstawy prawne ich funkcjonowania są uregulowane zarówno na szczeblu legislacji unijnej jak i krajowej. Zestawienie podstaw prawnych funkcjonowania ZIT w Polsce zostało zaprezentowane $w$ tabeli 1.

Realizacja instrumentu Zintegrowanych Inwestycji Terytorialnych jest możliwa przy spełnieniu następujących warunków:

1. Zawiązanie zinstytucjonalizowanej formy partnerstwa (powołanie Związku ZIT/Partnerstwa ZIT). Związki ZIT będą pełnić funkcję wspólnej reprezentacji władz miast i obszarów powiązanych z nimi funkcjonalnie wobec władz krajowych i regionalnych.

2. Przygotowanie Strategii ZIT - podstawowego dokumentu w zakresie udzielenia wsparcia $\mathrm{z}$ działań/priorytetów realizowanych w formule ZIT w ramach RPO.

3. Posiadanie odpowiedniej zdolności instytucjonalnej - w systemie instytucjonalnym RPO powołane partnerstwa pełnią rolę Instytucji Pośredniczących (IP ZIT).

4. Podpisanie porozumienia do realizacji ZIT w województwie pomiędzy Związkiem ZIT/ Porozumieniem ZIT a Instytucją Zarządzającą RPO.

5. Zawarcie stosownych zapisów w RPO spełniających wymogi KE oraz zgodnych z zapisami Umowy Partnerstwa (MIiR 2015, s. 11).

Zintegrowane Inwestycje Terytorialne będą realizowane głównie na terenie miast wojewódzkich i obszarów powiązanych z nimi funkcjonalnie $\mathrm{w}$ ramach RPO. Zgodnie z definicją zawartą w Koncepcji Przestrzennego Zagospodarowania Kraju 2030 miejski obszar funkcjonalny (MOF) to układ osadniczy ciągły przestrzennie, który złożony jest z jednostek odrębnych administracyjnie. Obejmuje on zwarty obszar 
Table 1. The legal basis for ITI functioning in Poland

Tabela 1. Podstawy prawne funkcjonowania ZIT w Polsce

\begin{tabular}{|c|c|}
\hline $\begin{array}{c}\text { Legislation level/ } \\
\text { Szczebel legislacji }\end{array}$ & List of legal acts/ Wykaz aktów prawnych \\
\hline $\begin{array}{l}\text { The level } \\
\text { of the European Union/ } \\
\text { Poziom Unii Europejskiej }\end{array}$ & 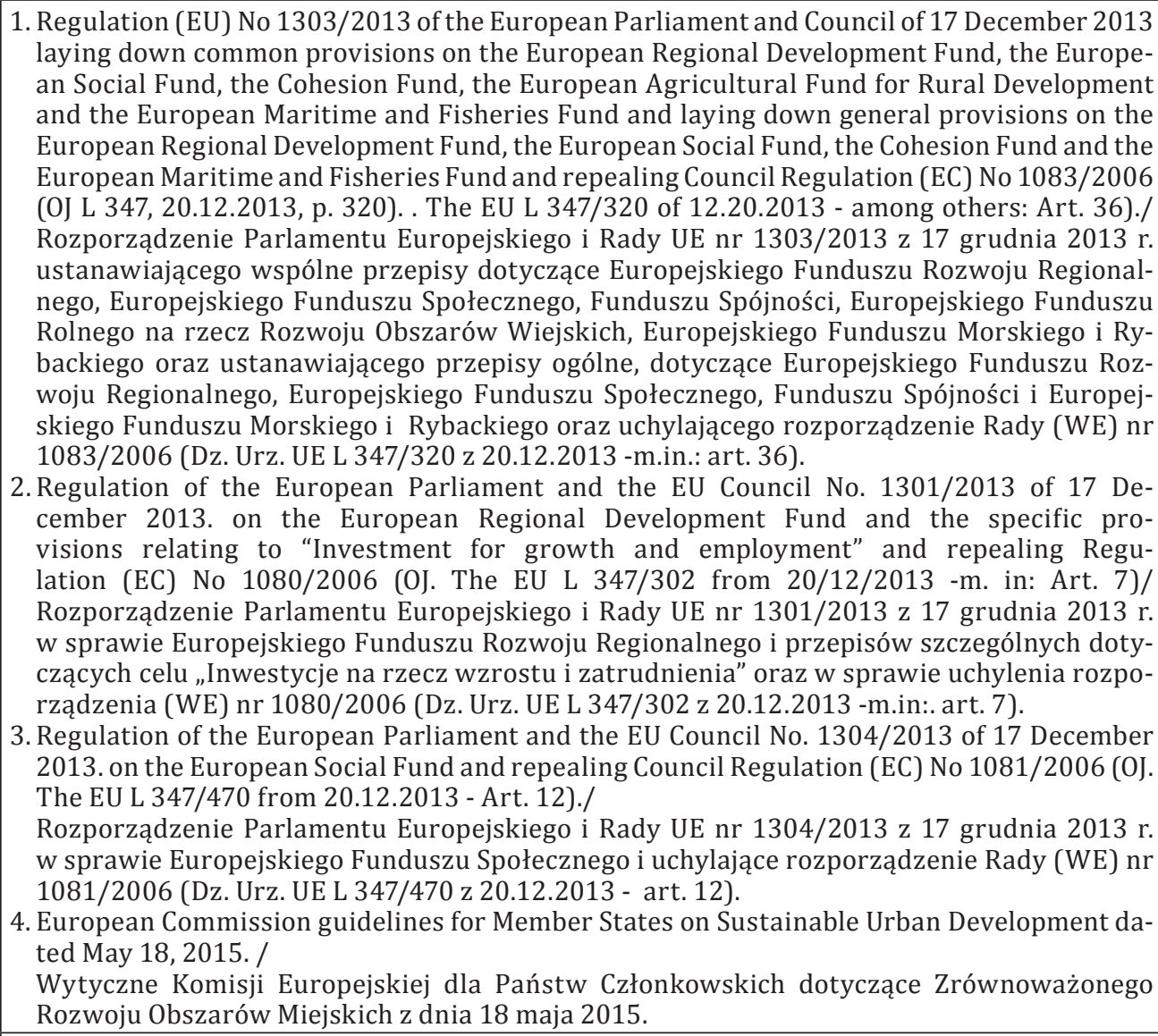 \\
\hline $\begin{array}{l}\text { Polish level/ } \\
\text { Poziom Polski }\end{array}$ & $\begin{array}{l}\text { 1. The Act of } 11 \text { July 2014. On the implementation of programs in the field of cohesion policy fi- } \\
\text { nanced in the 2014-2020 financial perspective (J. L. 2014, item 1146, as amended. - Art. 30)./ } \\
\text { Ustawa z } 11 \text { lipca } 2014 \text { r. o realizacji programów w zakresie polityki spójności finansowa- } \\
\text { nych w perspektywie finansowej 2014-2020 (Dz. U. z 2014 r. poz. 1146 ze zm. - art. 30). } \\
\text { 2. Partnership Agreement Poland-European Union. } 2014 \text { (http: // ec. europa.eu/contracts_- } \\
\text { grants/pa/partnership-agreement-poland_pl.pdf. 07/10/2016 - Point 3.1.2)./ } \\
\text { Umowa Partnerstwa Polska-Unia Europejska. 2014. (http://ec. europa.eu/contracts_grants/ } \\
\text { pa/partnership-agreement-poland_pl.pdf. } 10.07 .2016 \text { - punkt 3.1.2). } \\
\text { 3. The guidelines of the Ministry of Regional Development of July 2013. On the rules for the } \\
\text { implementation of integrated territorial investments in Poland./ } \\
\text { Wytyczne Ministerstwa Rozwoju Regionalnego z lipca } 2013 \text { r. w sprawie zasad realizacji } \\
\text { zintegrowanych inwestycji terytorialnych w Polsce. } \\
\text { 4. Guidelines of the Minister of Infrastructure and Development regarding modes of selection } \\
\text { of projects for the 2014-2020 period of } 31 \text { March } 2015 \text {./ } \\
\text { Wytyczne Ministra infrastruktury i Rozwoju w zakresie trybów wyboru projektów na lata } \\
\text { 2014-2020 z } 31 \text { marca } 2015 \text { r. }\end{array}$ \\
\hline
\end{tabular}

Source: own elaboration.

Źródło: Opracowanie własne.

together with an urbanized zone functionally linked to it - rural, urban and rural-urban communes may be included in it. ${ }^{2}$ UFAs can be divided into four subtypes: province centres (including metropolitan ones), as well as regional, sub-regional and local centres. This typology is related to the function of urban centres

\footnotetext{
${ }^{2}$ While indicating other communes as part of the functional area, the following indicators were taken into account: the number of commuters and schools, the number of residence registrations from the core Functional Urban Areas of Provincial Centres (UFA PC), the share of people working in non-agricultural professions, number of economic operators, population density, housing growth rate.
}

miejski wraz z powiązaną z nim funkcjonalnie strefą zurbanizowaną - może obejmować gminy wiejskie, miejskie i miejsko-wiejskie. ${ }^{2}$ MOF podzielić można na cztery podtypy: ośrodki wojewódzkie (w tym metropolitalne), regionalne, subregionalne oraz lokalne. Typologia ta związana jest $\mathrm{z}$ funkcją ośrodków

\footnotetext{
2 Wskazujac pozostałe gminy do obszaru funkcjonalnego brano pod uwage takie wskaźniki jak: liczba osób dojeżdżajacych do pracy i szkół, liczbę zameldowań z rdzenia MOF OW, udział osób pracy i szkół, liczbę zameldowan z rdzenia MOF OW, udział osób
pracujących w zawodach pozarolniczych, liczbę podmiotów gospodarczych, gęstość zaludnienia, dynamikę przyrostu budownictwa mieszkaniowego.
} 
in the settlement system of a country and is mainly based on their size. The delimitation of functional areas and preparation of strategies and development plans for various functional areas, contributes to enhancing the spatial integrity of the centres, which encourages the development of all Polish regions (MRR 2012 p.191). The Ministry of Regional Development has prepared a document titled: Criteria for delimitation of urban functional areas of province centres. It is the basis for distinguishing a "provincial ITI" area. Integrated Territorial Investments will be realized in the areas constituting a territory covered by a "provincial ITI", which will have to consist of a provincial capital, along with the cities belonging to the core urban functional areas in provincial centres and other communes of the functional area (at least half of the communes, which have been selected on the basis of the abovementioned document). In total, ITI will be implemented in 24 functional areas, including 17 functional areas of provincial cities and 7 in the functional areas of sub-regional/regional towns in four provinces: Śląskie, Dolnośląskie, Wielkopolskie and Zachodniopomorskie. Table 2 shows a list of ITI in Poland.

The most extensive study of all delimitation collections developed in Poland to date is the study prepared within the project ESPON 1.4.3 "Study on urban functions". The study concerned the delimitation of functional urban areas and took into account 151 largest Polish cities. The delimitation was carried out in accordance with the following principles:

1. administrative ones - related to distinguishing and location of core and external zones. The city - the capital of a province - is the core;

2. topological - involving the use of the cohesion (functional urban area should be spatially continuous) and separability condition (each of the communes can belong to only one functional urban area),

3. fulfilment of the criteria - related to meeting functional, socio-economic and morphological indicators by particular communes (Sleszyński 2013, p. 182-183).

Taking into account the guidelines contained in the document: The criteria for the delimitation of functional urban areas belonging to provincial centres as well as arrangements with communes from the UFA PC which are interested in cooperation, an implementation area of "Provincial ITI" is established pursuant to the resolution of the provincial management board. Units of local government, which will belong to the functional urban areas of the provincial centre, but will not want to join the ITI implementation area, are likely to have limited access to other modes of granting various types of support under the ROP in the areas, where the ITI formula is planned.

Under Article 30 section 4 of the cited Act on the principles of implementing programs in the field of cohesion policy financed in the 2014-2020 financial perspective (i.e. Implementation Act) ITI will be managed by an ITI Association, which is created as forms of cooperation of JSTs or by JSTs under a contract miejskich w osadniczym systemie kraju i opiera się głównie o ich wielkość. Delimitacja obszarów funkcjonalnych i przygotowanie strategii oraz planów zagospodarowania dla poszczególnych obszarów funkcjonalnych wpływa na wzmacnianie przestrzennej integralności ośrodków, co służy rozwojowi wszystkich regionów Polski (MRR 2012, s.191). Ministerstwo Rozwoju Regionalnego przygotowało dokument pt. Kryteria delimitacji miejskich obszarów funkcjonalnych ośrodków wojewódzkich (MOF OW). Na jego podstawie wyznaczany jest obszar „ZIT wojewódzkiego". Zintegrowane Inwestycje Terytorialne realizowane będą na obszarach stanowiących terytorium objęte „ZIT wojewódzkim”, w skład którego wchodzić musi miasto wojewódzkie wraz z miastami z rdzenia MOF OW i innymi gminami obszaru funkcjonalnego (minimum połowa gmin, które wyznaczone zostały na podstawie ww. dokumentu). W sumie ZIT będą realizowane na 24 obszarach funkcjonalnych, w tym na 17 obszarach funkcjonalnych miast wojewódzkich oraz 7 na obszarach funkcjonalnych miast subregionalnych/regionalnych w czterech województwach: Śląskim, Dolnośląskim, Wielkopolskim oraz Zachodniopomorskim. W tabeli 2 przedstawiono wykaz ZIT w Polsce.

Najbardziej obszernym z opracowanych dotychczas w Polsce zbiorów delimitacyjnych jest opracowanie przygotowane $w$ ramach projektu ESPON 1.4.3 "Study on urban functions". Opracowanie to dotyczyło delimitacji Funkcjonalnych Obszarów Miejskich i uwzględniono w nim 151 największych polskich miast. Delimitacja została dokonana zgodnie z następującymi zasadami:

1. administracyjnymi - związane z rozróżnieniem oraz położeniem rdzeni i stref zewnętrznych. Rdzeń stanowi miasto - stolica województwa;

2. topologicznymi - polegające na zastosowaniu warunku spójności (obszar MOF ma być ciągły przestrzennie) oraz rozłączności (każda z gmin może należeć tylko do jednego MOF),

3. spełnienia kryteriów - związane ze spełnianiem przez poszczególne gminy wskaźników funkcjonalnych, społeczno-gospodarczych oraz morfologicznych (Śleszyński 2013, s. 182 - 183).

Biorąc pod uwagę wytyczne zawarte w dokumencie: Kryteria delimitacji miejskich obszarów funkcjonalnych ośrodków wojewódzkich, a także uzgodnienia z gminami z obszaru MOF OW, które są zainteresowane współpracą, uchwałą zarządu województwa wyznacza się obszar realizacji „ZIT wojewódzkiego”. Jednostki samorządu terytorialnego, które będa należały do MOF OW, lecz nie będą chciały przystąpić do obszaru realizacji ZIT prawdopodobnie będą miały utrudniony dostęp do pozostałych trybów udzielania różnego rodzaju wsparcia w ramach RPO w tych obszarach, dla których przewidziana jest formuła ZIT.

Zgodnie z treścią art. 30 ust. 4 cytowanej ustawy o zasadach realizacji programów w zakresie polityki spójności finansowanych w perspektywie finansowej 2014-2020 (tzw. ustawa wdrożeniowa) ZIT zarządzane będą przez Związek ZIT, który tworzony jest 
Table 2. The list of ITI in Poland, together with figures on LGUs included in them

Tabela 2. Wykaz ZIT w Polsce wraz z zestawieniem liczebnym JST wchodzących w ich skład

\begin{tabular}{|c|c|c|}
\hline $\begin{array}{c}\text { Functional Urban Areas/ } \\
\text { Miejskie Obszary Funkcjonalne }\end{array}$ & $\begin{array}{c}\text { legal form: } \\
\text { Association or agreement/ } \\
\text { Forma prawna:Stowarzyszenie lub porozumienie }\end{array}$ & $\begin{array}{l}\text { Number of LGU/ } \\
\text { Liczba JST }\end{array}$ \\
\hline Białystok & $\begin{array}{l}\text { Association of Białystok Functional Area/ } \\
\text { Stowarzyszenie Białostockiego Obszaru Funkcjonal- } \\
\text { nego }\end{array}$ & 10 \\
\hline Bielsko-Biała & Agreement/ Porozumienie & 41 \\
\hline Bydgoszcz-Toruń & Agreement/ Porozumienie & 25 \\
\hline Częstochowa & Agreement/ Porozumienie & 34 \\
\hline Gdańsk-Gdynia-Sopot & $\begin{array}{l}\text { Association of the Metropolitan Gdańsk-Gdynia-Sopot } \\
\text { area/ } \\
\text { Stowarzyszenie Obszar Metropolitarny Gdańsk-Gdy- } \\
\text { nia-Sopot }\end{array}$ & 36 \\
\hline Gorzów Wielkopolski & Agreement/ Porozumienie & 5 \\
\hline Jelenia Góra & Agreement/ Porozumienie & 18 \\
\hline Kalisz-Ostrów Wielkopolski & $\begin{array}{l}\text { Association of Kalisz-Ostrów } \\
\text { Agglomeration/ } \\
\text { Stowarzyszenie AglomeracjaKalisko-Ostrowska }\end{array}$ & 24 \\
\hline Katowice/Gliwice & $\begin{array}{l}\text { Association - Union of Communes and Central Sub-re- } \\
\text { gion/ } \\
\text { Stowarzyszenie Związek Gmin i Subregionu Central- } \\
\text { nego }\end{array}$ & 81 \\
\hline $\begin{array}{c}\text { Kielce } \\
\end{array}$ & Agreement/ Porozumienie & 12 \\
\hline Koszalin-Kołobrzeg-Białogard & Agreement/ Porozumienie & 19 \\
\hline Kraków & $\begin{array}{l}\text { Kraków Metropolitan Association/ } \\
\text { Stowarzyszenie Metropolia Krakowska }\end{array}$ & 15 \\
\hline Lublin & Agreement/ Porozumienie & 16 \\
\hline Łódź & $\begin{array}{l}\text { Łódź Metropolitan Area Association/ } \\
\text { Stowarzyszenie Łódzki Obszar Metropolitarny }\end{array}$ & 31 \\
\hline Olsztyn & Agreement/ Porozumienie & 7 \\
\hline Opole & \begin{tabular}{|l|} 
Association of Opole Agglomeration/ \\
Stowarzyszenie Aglomeracji Opolskiej
\end{tabular} & 21 \\
\hline Poznań & \begin{tabular}{|l|} 
Poznań Metropolitan Association/ \\
Stowarzyszenie Metropolia Poznań
\end{tabular} & 23 \\
\hline Rybnik & $\begin{array}{l}\text { Association Union of Communes } \\
\text { and Counties of the Western Sub-region/ } \\
\text { Stowarzyszenie Związek Gmini Powiatów Subregionu } \\
\text { Zachodniego }\end{array}$ & 28 \\
\hline Rzeszów & Agreement/ Porozumienie & 13 \\
\hline Szczecin & $\begin{array}{l}\text { Szczecin Metropolitan Area Association/ } \\
\text { Stowarzyszenie Szczecińskiego Obszaru Metropoli- } \\
\text { tarnego }\end{array}$ & 13 \\
\hline Wałbrzych & Agreement/ Porozumienie & 22 \\
\hline Warsaw & Agreement/ Porozumienie & 40 \\
\hline Wrocław & Agreement/ Porozumienie & 15 \\
\hline Zielona Góra & Agreement/ Porozumienie & 5 \\
\hline TOTAL & \multicolumn{2}{|l|}{350} \\
\hline
\end{tabular}

Source: Ministry of Infrastructure and Development 2015, p. 29.

Źródło: MIiR 2015, s. 29.

or agreement on cooperation for the purpose of joint ITI implementation.

\section{ITI strategy - the basis for granting EU support}

The condition of ITI implementation is the possession of a strategic document. Under Article 7 of the cited regulation on the European Regional w formach współpracy JST albo przez JST na podstawie umowy lub porozumienia o współpracy w celu wspólnej realizacji ZIT.

\section{Strategia ZIT - podstawa udzielenia wsparcia unijnego}

Warunkiem realizacji ZIT jest posiadanie strategicznego dokumentu. Zgodnie z treścią art. 7 cytowanego 
Development Fund, ITI strategy is supposed to define integrated measures applied to solving the economic, environmental, climatic, demographic and social challenges affecting urban areas, including the need to promote urban-rural connections. The components of the ITI strategy can be assigned to three substantive areas:

1. The ITI Strategy support area together with priorities to be implemented within the ITI (based on a SWOT analysis).

2. The list of projects to be implemented in the ITI formula and rules for the selection of projects.

3. The terms of ITI implementation (financial plan, implementation system, implementation progress report).

The provisions of the ITI strategy must be consistent with the aforementioned legal foundation of ITI implementation. It constitutes a kind of compromise between the interests of the EU and regional needs of a given EU member state. Compromises in this area are, however, a condition sine qua non for the possibility of presenting a EC proposal for a long-term strategy adjusting strategies for sustainable economic, social and environmental development. Already in 1987, the World Commission on Environment and Development (Brundtland Commission) concluded that sustainable development should be seen as a global goal.

\section{Integrated Territorial Investments - principles of enterprise financing}

The implementation of the ITI cohesion policy requires adequate financial security. In Poland, this objective is planned to be funded by atleast $5.2 \%$ of the allocation from the European Regional Development Fund (ERDF) and by $2.4 \%$ of the allocation from the European Social Fund (ESF). The dual-fund sources of financing for ITI imply not only a wider range of activities that can be realised with their use, but also different levels of risk analysis of the projects financed with their use (EC 2015, p. 67-75). In Poland access to these funds is in the first place planned within16 ROPs. The value of the funds allocated for the implementation of the ITI in a provincial system is presented in Table 3. In all provinces the value of ERDF funds far exceeds the value of ESF funds. The majority of funds for ITI implementation were assigned to Śląskie province (484 million euros), while the least to Warmińsko-Mazurskie province (45.2 million euros).

It is worth noting that projects resulting from the ITI strategy and having complementary character to the projects supported by ROP in the ITI formula, will also be able to obtain the support of national programs (primarily from the Operational Programme Eastern Poland and the Operational Programme Infrastructure and Environment 20142020). It should be emphasised that the possibility of co-financing the complementary project (funded by the National Operational Programme) will be rozporządzenia o Europejskim Funduszu Rozwoju Regionalnego strategia ZIT ma określać zintegrowane działania służące rozwiązywaniu problemów gospodarczych, środowiskowych, klimatycznych, demograficznych i społecznych jakich doświadczają obszary miejskie, $\mathrm{z}$ uwzględnieniem potrzeby wspierania powiązań między obszarami miejskimi i wiejskimi. Elementy składowe strategii ZIT można przyporządkować do trzech obszarów merytorycznych:

1. Obszar wsparcia Strategii ZIT wraz z priorytetami do realizacji w ramach ZIT ( $w$ oparciu o analizę SWOT).

2. Lista przedsięwzięć do realizacji w formule ZIT oraz zasady wyboru projektów.

3. Warunki realizacji ZIT (plan finansowy, system wdrażania, sprawozdanie z przebiegu prac).

Zapisy strategii ZIT muszą być zgodne z wymienionymi wcześniej podstawami prawnymi implementacji ZIT. Stanowi to swoisty kompromis pomiędzy interesami UE a potrzebami regionalnymi poszczególnego kraju członkowskiego UE. Kompromisy w tym obszarze stanowią jednak warunek sine qua non możliwości prezentowania przez KE propozycji długoterminowej strategii dopasowującej strategie na rzecz rozwoju zrównoważonego ekonomicznie, społecznie i ekologicznie. Już bowiem w 1987 r. Światowa komisja do spraw

Środowiska i Rozwoju (Komisja Brundtlanda) uznała, że rozwój zrównoważony należy postrzegać jako cel globalny.

\section{Zintegrowane Inwestycje Terytorialne - zasady finansowania przedsięwzięć}

Implementacja polityki spójności w układzie ZIT wymaga odpowiedniego zabezpieczenia finansowego. W Polsce na ten cel planuje się przeznaczyć co najmniej 5,2\% alokacji Europejskiego Funduszu Rozwoju Regionalnego (EFRR) i 2,4\% alokacji Europejskiego Funduszu Społecznego (EFS). Dwufunduszowe źródła finansowania ZIT oznaczają nie tylko szersze spektrum działań możliwych do zrealizowania z ich użyciem, ale także zróżnicowane poziomy analizy ryzyk projektów sfinansowanych z ich użyciem (EC 2015 b, p. 67 - 75). Dostęp do tych funduszy w Polsce jest przede wszystkim zaplanowany $w$ ramach 16 RPO. Wartość środków finansowych przeznaczonych na realizację ZIT w układzie województw przedstawiono w tabeli 3. We wszystkich województwach wartość środków z EFRR znacznie przewyższa wartość z EFS. Najwięcej środków na realizację ZIT zaplanowano $\mathrm{w}$ województwie śląskim (484 mln euro), natomiast najmniej w województwie warmińsko-mazurskim (45,2 mln euro).

Warto podkreślić, iż wynikające ze Strategii ZIT projekty o charakterze komplementarnym do projektów wspieranych przez RPO w formule ZIT będą miały możliwość uzyskania wsparcia także z programów krajowych (przede wszystkim z Programu Operacyjnego Polska Wschodnia oraz Programu Operacyjnego Infrastruktura i Środowisko 2014-2020). Podkreślić należy, że możliwość dofinansowania komplementarnego projektu (finansowanego z krajowego programu 
Table 3. The funds allocated for the Integrated Territorial Investment implementation in a provincial system

Tabela 3. Środki przeznaczone na realizację Zintegrowanych Inwestycji Terytorialnych w układzie województw

\begin{tabular}{|c|c|c|c|}
\hline \multirow[t]{2}{*}{$\begin{array}{c}\text { Province/ } \\
\text { Województwo }\end{array}$} & \multirow[t]{2}{*}{$\begin{array}{c}\text { Total ITI (million euros)/ } \\
\text { ZIT wojewódzkie łącznie } \\
\text { (mln euro) }\end{array}$} & \multicolumn{2}{|c|}{$\begin{array}{l}\text { including:/ } \\
\text { w tym: }\end{array}$} \\
\hline & & $\begin{array}{l}\text { ERDF (million euros)/ } \\
\text { EFRR (mln euro) }\end{array}$ & $\begin{array}{c}\text { ESF (million euros)/ } \\
\text { EFS (mln euro) }\end{array}$ \\
\hline Dolnośląskie & 173.0 & 155.9 & 17.0 \\
\hline Kujawsko-Pomorskie & 153.8 & 135.7 & 18.1 \\
\hline Lubelskie & 105.4 & 93.3 & 12.1 \\
\hline Lubuskie & 66.6 & 58.9 & 7.7 \\
\hline Łódzkie & 203.5 & 180.2 & 23.3 \\
\hline Małopolskie & 229.9 & 201.5 & 28,4 \\
\hline Opolskie & 46 & 40.9 & 5.1 \\
\hline Podkarpackie & 70.8 & 62.8 & 8,0 \\
\hline Podlaskie & 75.8 & 67.2 & 8.6 \\
\hline Pomorskie & 215.8 & 189.4 & 26.4 \\
\hline Ślq̨skie & 484.0 & 421.7 & 62.3 \\
\hline Świętokrzyskie & 62.3 & 56.5 & 5.8 \\
\hline Warmińsko-Mazurskie & 45.2 & 42.1 & 3.1 \\
\hline Wielkopolskie & 178.6 & 158.4 & 20.2 \\
\hline Zachodniopomorskie & 109.1 & 97.9 & 11.2 \\
\hline $\begin{array}{l}\text { TOTAL 15/ } \\
\text { RAZEM } 15 \\
\end{array}$ & 2220.0 & $1,971.2$ & 248.8 \\
\hline Mazowieckie & 164.8 & 141.1 & 23.7 \\
\hline $\begin{array}{l}\text { TOTAL 16/ } \\
\text { RAZEM } 16\end{array}$ & $2,384.8$ & $2,112.3$ & 272.6 \\
\hline
\end{tabular}

Source: Programming the Financial Perspective 2014-2020 - Partnership Agreement. The Ministry of Infrastructure and Development, Warsaw 2014, p.213.

Źródło: Programowanie perspektywy finansowej 2014-2020 - Umowa Partnerstwa.. Ministerstwo Infrastruktury i Rozwoju, Warszawa 2014, s.213.

the subject of negotiations between institutions managing operational programs, the managing authority of the ROP and the ITI Association (Ministry of Regional Development 2013, p. 3). Together with the aforementioned national operational programs the implementation of the ITI strategies will be funded with approx. 6.2 billion euros ${ }^{3}$.

Projects selected in the ITI formula must meet the following requirements:

1. possession of an integrated ${ }^{4}$ and complementary character - they must complement one another with respect to the geographical, thematic and functional aspects of other projects that have been completed or are currently being implemented. Integrated projects must provide a comprehensive response to the problems of a particular functional area. In addition, they must combine different financial sources (ERDF and ESF) and measures (so-called "soft" and "hard").

2. They must be created in partnership - projects implemented in the ITI formula should be consulted with many partners - both within ITI Associations/Partnerships and other entities

\footnotetext{
${ }^{3}$ https://www.funduszeeuropejskie.gov.pl/strony/o-funduszach/zasady-dzialania-funduszy/zintegrowane-inwestycje-terytorialne. (accessed: 01/08/2016).

${ }^{4}$ Pursuant to Art. 32 of the Implementation Act, an integrated project consists of at least two projects linked thematically into a common goal, which is to be achieved through their implementation.
}

operacyjnego) stanowić będzie przedmiot negocjacji pomiędzy instytucjami zarządzającymi programami operacyjnymi, instytucją zarządzającą RPO oraz Związkiem ZIT (MRR 2013, s. 3). Łącznie z ww. krajowymi programami operacyjnymi na realizację strategii ZIT przeznaczona jest kwota ok. 6,2 mld euro ${ }^{3}$.

Projekty wybierane w formule ZIT muszą spełniać następujące cechy:

1. Mieć charakter zintegrowany ${ }^{4}$ i komplementarny - uzupełniać się pod względem geograficznym, tematycznym i funkcjonalnym z innymi przedsięwzięciami, które zostały już zrealizowane lub są realizowane obecnie. Zintegrowane projekty muszą stanowić kompleksową odpowiedź na problemy danego obszaru funkcjonalnego. Ponadto muszą łączyć różne źródła finansowe (EFRR oraz EFS) oraz działania (tzw. „miękkie” i „twarde”).

2. Być tworzone w partnerstwie - projekty realizowane $\mathrm{w}$ formule ZIT powinny być uzgadniane między wieloma partnerami - zarówno w ramach Związków ZIT/Partnerstw oraz innych

\footnotetext{
${ }^{3}$ https://www.f unduszeeuropejskie.gov.pl/strony/o-funduszach/zasady-dzialania-funduszy/zintegrowane-inwestycje-terytorialne. (data dostepu: 01.08.2016).

${ }^{4}$ Zgodnie z art. 32 ustawy wdrożeniowej projekt zintegrowany to co najmniej dwa projekty powiązane ze sobą tematycznie w ramach wspólnego celu, jaki ma zostać osiągnięty dzięki ich realizacji.
} 
functioning in a given area: entrepreneurs, social groups, organisations and residents. It is also important to agree the planned projects with the Managing Authorities which will finance particular investments ${ }^{5}$.

3. Projects ready for implementation - must be realistic and have a clearly specified concept, work schedule, project documentation, plans for the construction etc. (MIiR 2015, p. 4).

From the assumptions mentioned above it can be concluded that the responsibility of local governments for investing EU funds within ITI will be greatly increased. The premise for the implementation of ITI strategy is that local authorities are to be responsible for preparing the projects because they know the local conditions best and the projects developed by them will be best suited to their development needs. A problem may be posed by the lack of sufficient willingness of local authorities towards the actual integration of development objectives and insufficient ability to analyse their own socio-economic problems also from the perspective of, e.g. neighbouring JSTs. Provision of training for local government personnel, with high efficiency indicators would be useful (Kirkpatrick 1994, Philips 2003).

\section{Investment directions within the ITI strategy on the example of Kalisz-Ostrów Agglomeration}

Investment directions, as part of ITI for KaliszOstrów Agglomeration, are related to the territory designated by the Managing Board of Wielkopolskie province with Resolution No. 4014/2013 of 7 November 2013, in the framework of Wielkopolska Regional Operational Programme for 2014-2020. These directions were presented in the strategy adopted in April 2016 by the Ministry of Development and the Managing Authority of Wielkopolska Regional Operational Programme for 2014-2020. the following problems of this area were diagnosed in the KOA ITI strategy:

1. economic ones (slow pace of economic growth, low investment attractiveness of the KOA area; low level of support for entrepreneurship; low level of cooperation between KOA entrepreneurs; unsatisfactory state of road infrastructure maladjusted to the intensified traffic and insufficient throughput of the existing connections and low intra-regional accessibility, difficulties with the Internet access and the lack of integration in e-services);

2. environmental ones (poor capacity for adequate programming processes of revitalization; numerous deficiencies in technical infrastructure: difficulties in accessing water and sewage

\footnotetext{
${ }^{5}$ As part of the accounting records, the funds obtained from a EU grant will be transferred from budgetary classification sections number:

$2008-85 \%$ of the value of the received grants (financing) $2009-15 \%$ of the value of the received grants (co-financing). However, financial allocation for the implementation of capital expenditure is transferred from the sections of budgetary classification number:

$6208-85 \%$ of the value of the received grants (funding) $6209-15 \%$ of the value of the received grants (co-financing).
}

podmiotów funkcjonujących na danym terenie: przedsiębiorców, grup społecznych, organizacji, mieszkańców. Ważne jest także uzgodnienie planowanych projektów z Instytucjami Zarządzającymi, które będą dane inwestycje finansować 5 .

3. Gotowe do realizacji - projekty muszą być realistyczne, posiadać jasno sprecyzowaną koncepcję, harmonogram prac, dokumentację projektową, plany na budowę itd. (MIiR 2015, s. 4).

Z założeń powyższych można sformułować wniosek, iż odpowiedzialność samorządów lokalnych za inwestowanie unijnych środków w ramach ZIT zostanie znacznie zwiększona. Założeniem bowiem strategii realizacji ZIT jest to, że za przygotowanie projektów mają odpowiadać władze szczebla lokalnego, gdyż to one najlepiej znają lokalne uwarunkowania, a opracowane przez nie projekty będą najlepiej odpowiadać na ich potrzeby rozwojowe. Problemem może być jednak brak wystarczającej chęci władz samorządowych do faktycznej integracji celów rozwojowych oraz brak umiejętności analizowania własnego problemu społeczno - gospodarczego także z perspektywy np. sąsiednich JST. Użyteczne byłyby szkolenia dla kadry samorządowej o wysokim wskaźniku efektywności (Kirkpatrick 1994, Philips 2003).

\section{Kierunki inwestycji w ramach strategii ZIT na przykładzie Aglomeracji Kalisko-Ostrowskiej}

Kierunki inwestycji w ramach ZIT dla Aglomeracji Kalisko-Ostrowskiej dotyczą terytorium wyznaczonego przez Zarząd Województwa Wielkopolskiego uchwałą Nr 4014/2013 z dnia 7 listopada 2013 r. W ramach Wielkopolskiego Regionalnego Programu Operacyjnego na lata 2014-2020. Kierunki te zostały zaprezentowane w strategii przyjętej w kwietniu 2016 r. przez Ministerstwo Rozwoju oraz Instytucję Zarządzającą Wielkopolskim Regionalnym Programem Operacyjnym na lata 2014-2020. W strategii ZIT AKO zdiagnozowano następujące problemy tego terenu:

1. gospodarcze (zbyt wolne tempo rozwoju gospodarczego; niska atrakcyjność inwestycyjna terenu AKO; niski poziom wspierania przedsiębiorczości; niski poziom współpracy pomiędzy przedsiębiorcami AKO; niezadowalający stan infrastruktury drogowej niedostosowanej do natężonego ruchu samochodowego i niewystarczająca przepustowość istniejących połączeń oraz niska dostępność komunikacyjna wewnątrzregionalna; utrudnienia w dostępnie do sieci internetowej oraz brak integracji e-usług);

2. środowiskowe (słaba zdolność do właściwego programowania procesów rewitalizacyjnych; liczne braki w zakresie infrastruktury technicznej: trudności z dostepem do sieci wodociągowej i kanalizacyjnej, konieczność budowy

${ }^{5}$ W ramach ewidencji księgowej środki otrzymanej dotacji unijnej będą przekazywane z paragrafów klasyfikacji budżetowej numer:

2008 - 85\% wartości otrzymanej dotacji (finansowanie) 2009 - 15\% wartości otrzymanej dotacji (współfinansowanie). Natomiast środki na realizację wydatków majątkowych są przekazywane z paragrafów klasyfikacji budżetowej numer: $6208-85 \%$ wartości otrzymanej dotacji (finansowanie) 6209 - 15\% wartości otrzymanej dotacji (współfinansowanie). 
networks, necessity of constructing wastewater treatment plants, large disparities in accessibility between water supply networks and sewage systems, related to ecological threats, low gas network availability, lack of rainwater collectors, reservoirs, shortage of installations for the disposal of waste, air pollution);

3. demographic ones (low population growth; negative internal migration balance, ageing population);

4. social ones (high percentage of people benefiting from social assistance; poor integration of provided education with labour market needs; low accessibility to medical care; depreciation of culture services and cultural heritage facilities, as well as the poor condition of historic and cultural buildings contributing to low tourist attractiveness) (KOA Council 2016).

Based on this diagnosis, the vision of developing KOA was determined on the basis of the following logical sequence of actions: diagnosis of a functional area; identification of problems/potentials; defining (objectives, investment priorities, measures); selection of projects (Jaspers 2014).

As a result of SWOT analysis, it was concluded that EU funds within the KOA ITI should be used for the implementation of the following priorities:

1. Supporting entrepreneurship, employment and occupational activity. The aim is to strengthen the economic development of KOA, entrepreneurship, employment and occupational activity.

2. Promotion of low-carbon strategies. The aim is to improve the environment condition in the area of KOA, supporting energy efficiency and promoting low-carbon strategies through the implementation of ecological projects in the Agglomeration area and the development of a sustainable public transport system in KOA.

3. Educated society. The aim is to develop secondary education and vocational/continuous education.

4. Modern infrastructure for development. The goal is to restore social and economic functions of degraded urban and rural KOA areas and the creation of modern infrastructure in the Agglomeration area, including communication and information infrastructure by improving accessibility and quality of public services throughout the functional area, development of water and sewage infrastructure, road infrastructure and cultural institutions and protection of national heritage.

All of the demonstrated priorities are in line with the objectives of the Cohesion Policy 20142020. This is proven, among others, by the fact of their compliance with the objectives of the Europe 2020 Strategy, i.e.:

- Smart growth; developing economy based on knowledge and innovation.

- Sustainable growth: promoting a more resource-efficient, environmentally friendly and competitive economy. oczyszczalni ścieków, duże dysproporcje w dostępie pomiędzy siecią wodociągową, a siecią kanalizacyjną związane z zagrożeniami ekologicznymi, mała dostępność do sieci gazowej, brak kolektorów na wody deszczowe, zbiorników retencyjnych, niedobór $\mathrm{w}$ instalacjach związanych z utylizacją odpadów; zanieczyszczenie powietrza);

3. demograficzne (nieznaczny wzrost liczby ludności; ujemne saldo migracji wewnętrznych; starzenie się społeczeństwa);

4. społeczne (wysoki odsetek osób korzystających z pomocy społecznej; słaba integracja realizowanego kształcenia z potrzebami rynku pracy; niska dostępność do opieki medycznej; dekapitalizacja obiektów usług kultury i dziedzictwa kulturowego oraz zły stan obiektów zabytkowych i kulturalnych wpływający na niską atrakcyjność turystyczną) (Rada AKO 2016).

Na podstawie powyższej diagnozy określono wizję rozwoju AKO w oparciu o następujący ciąg logiczny działań: diagnozę obszaru funkcjonalnego; identyfikację problemów/potencjałów; zdefiniowanie (celów; priorytetów inwestycyjnych, działań); wybór projektów (Jaspers 2014).

W efekcie przeprowadzonej analizy SWOT uznano, że środki unijne w ramach ZIT AKO powinny być wykorzystane na realizację następujących priorytetów:

1. Wspieranie przedsiębiorczości, zatrudnienia oraz aktywności zawodowej. Celem jest wzmacnianie rozwoju gospodarczego AKO, przedsiębiorczości, zatrudnienia oraz aktywności zawodowej.

2. Promocja strategii niskoemisyjnych. Celem jest poprawa stanu środowiska na obszarze AKO, wspieranie efektywności energetycznej i promowanie strategii niskoemisyjnych poprzez wdrażanie proekologicznych przedsięwzięć na terenie Aglomeracji oraz rozwój zrównoważonego systemu transportu publicznego AKO.

3. Wykształcone społeczeństwo. Celem jest rozwój edukacji ponadgimnazjalnej i kształcenia zawodowego/ustawicznego.

4. Nowoczesna infrastruktura służąca rozwojowi. Celem jest przywracanie funkcji społeczno-gospodarczych zdegradowanych obszarów miejskich i wiejskich AKO oraz stworzenie na terenie Aglomeracji nowoczesnej infrastruktury, w tym komunikacyjno-informacyjnej poprzez poprawę dostępu i jakości usług publicznych na całym obszarze funkcjonalnym, rozwój infrastruktury wodno-kanalizacyjnej, infrastruktury drogowej oraz instytucji kultury i ochrona dziedzictwa narodowego.

Wszystkie wykazane priorytety są zbieżne z założeniami polityki spójności 2014 - 2020. Świadczy o tym m.in. fakt ich zgodności z celami Strategii Europa 2020 tj.:

- Rozwój inteligentny; rozwój gospodarki opartej na wiedzy i innowacji.

- Rozwój zrównoważony: wspieranie gospodarki efektywniej korzystającej z zasobów, bardziej przyjaznej i bardziej konkurencyjnej. 
- Development promoting social inclusion: supporting high-employment economy, ensuring social and territorial cohesion (KE 2010).

It should also be noted that the implementation of these priorities for actions is primarily conditioned by partnership and effective cooperation of local government units, not only within the core of the Agglomeration on the Kalisz-Ostrów Wielkopolski axis, but also throughout the Agglomeration area, which is made up of 24 local government units. However, at this stage of ITI implementation one cannot eliminate the risk stemming from the strongly ingrained individualism of JSTs in Polish regions, i.e. low social capital (Czapiński, Panek 2013).

\section{Subjective and objective scope of support under KOA ITI}

For the implementation of the KOA ITI, the Managing Board of Wielkopolskie province reserved funds from Wielkopolska Regional Operational Programme for 2014-2020, totalling 69.1 million euros, including the ERDF contribution of 61.3 million euros and ESF funds in the amount of 7,8 million euros. Table 4 . shows a list of measures envisaged for the implementation of the KOA ITI strategy.
- Rozwój sprzyjający włączeniu społecznemu: wspieranie gospodarki o wysokim poziomie zatrudnienia, zapewniającej spójność społeczną i terytorialną (KE 2010).

Warto także podkreślić, iż realizacja powyższych priorytetów działań warunkowana jest przede wszystkim partnerstwem oraz efektywną współpracą jednostek samorządu terytorialnego nie tylko w ramach rdzenia Aglomeracji na osi Kalisz-Ostrów Wielkopolski, ale również w całej przestrzeni Aglomeracji, którą tworzą 24 jednostki samorządowe. Nie można jednak na tym etapie wdrażania ZIT wyeliminować ryzyka dotyczącego mocno utrwalonego w polskich regionach indywidualizmu JST tj. niskiego kapitału społecznego (Czapiński, Panek 2013).

\section{Zakres podmiotowy i przedmiotowy wsparcia w ramach ZIT AKO}

Na realizację Strategii ZIT AKO Zarząd Województwa Wielkopolskiego zarezerwował środki w ramach alokacji Wielkopolskiego Regionalnego Programu Operacyjnego na lata 2014-2020 w łącznej wysokości 69,1 mln euro, w tym z EFRR w wysokości 61,3 mln euro oraz środki z EFS w wysokości 7,8 mln euro. W tabeli 4 przedstawiony został wykaz przewidzianych do realizacji działań w ramach strategii ZIT AKO.

Table 4. The measures within the framework of the ITI strategy for the development of KOA with the allocation of EU support Tabela 4. Działania w ramach strategii ZIT dla rozwoju AKO wraz z alokacją wsparcia unijnego

\begin{tabular}{|c|c|c|}
\hline $\begin{array}{l}\text { The measures in the KOA ITI } \\
\text { strategy/ } \\
\text { Działanie strategii ZIT AKO }\end{array}$ & $\begin{array}{l}\text { The main types of projects/ } \\
\text { Główne typy projektów }\end{array}$ & $\begin{array}{l}\text { Amount of } \\
\text { co-financing/ } \\
\text { Kwota dofi- } \\
\text { nansowania } \\
\quad[€]\end{array}$ \\
\hline $\begin{array}{l}\text { 1.1. Self-employment and } \\
\text { creation of new jobs,/ } \\
\text { 1.1.Samozatrudnienie oraz } \\
\text { tworzenie nowych miejsc } \\
\text { pracy. }\end{array}$ & $\begin{array}{l}\text { Diagnosis of professional competence in the field of conducting economic } \\
\text { activity; training and advisory services to prepare for starting and operating } \\
\text { economic activity; grants awarded for setting up a business. } \\
\text { Diagnoza kompetencji zawodowych w zakresie prowadzenia działalności } \\
\text { gospodarczej; szkolenia i doradztwo przygotowujące do rozpoczęcia i pro- } \\
\text { wadzenia działalności gospodarczej; udzielanie dotacji na rozpoczęcie dzia- } \\
\text { łalności gospodarczej. }\end{array}$ & 3460000.00 \\
\hline $\begin{array}{l}\text { 1.2 Supporting occupational } \\
\text { activity by pro-health } \\
\text { measures./ } \\
\text { 1.2.Wspieranie aktywności } \\
\text { zawodowej poprzez działania } \\
\text { prozdrowotne. }\end{array}$ & $\begin{array}{l}\text { Projects in the field of health prophylaxis, serving to support economic } \\
\text { activity, raise the level of health and reduce social inequality./ } \\
\text { Projekty w zakresie profilaktyki zdrowotnej służące wspieraniu aktywno- } \\
\text { ści zawodowej, podniesieniu poziomu zdrowia i zmniejszeniu nierówności } \\
\text { społecznej. }\end{array}$ & 985000.00 \\
\hline $\begin{array}{l}\text { 2.1. Low-emission public } \\
\text { transport system./ } \\
\text { 2.1. Niskoemisyjny system } \\
\text { transportu publicznego. }\end{array}$ & $\begin{array}{l}\text { Projects related to the sustainable urban mobility (among others: purchase of } \\
\text { low-emission transportation fleet, construction, reconstruction, expansion } \\
\text { of stops, integrated passenger transfer hubs, bicycle lanes); modernization } \\
\text { of bicycle paths; installation of energy-efficient street lighting. / } \\
\text { Projekty dotyczące zrównoważonej mobilności miejskiej (m.in.: zakup ni- } \\
\text { skoemisyjnego taboru; budowa, przebudowa, rozbudowa, przystanków, } \\
\text { zintegrowanych centrów przesiadkowych, pasów ruchu dla rowerów); mo- } \\
\text { dernizacja ścieżek rowerowych; montaż efektywnego energetycznie oświe- } \\
\text { tlenia ulicznego. }\end{array}$ & 18120000.00 \\
\hline $\begin{array}{l}\text { 2.2. Comprehensive thermal } \\
\text { efficiency improvement of } \\
\text { public utility buildings./ } \\
\text { 2.2.Kompleksowa termomod- } \\
\text { ernizacja budynków użytec- } \\
\text { zności publicznej. }\end{array}$ & $\begin{array}{l}\text { Comprehensive thermal efficiency improvement of public facilities in the } \\
\text { area of KOA./ } \\
\text { Kompleksowa modernizacja energetyczna budynków użyteczności publicz- } \\
\text { nej z terenu AKO. }\end{array}$ & 12865000.00 \\
\hline
\end{tabular}




\begin{tabular}{|c|c|c|}
\hline $\begin{array}{l}\text { 3.1. Ensuring equal access to } \\
\text { high-quality education./ } \\
\text { 3.1.Zapewnienie równego } \\
\text { dostępu do dobrej jakości } \\
\text { edukacji. }\end{array}$ & $\begin{array}{l}\text { Vocational education of youth and adults in the KOA area./ } \\
\text { Edukacja na poziomie zawodowym młodzieży oraz kształcenie zawodowe } \\
\text { dorosłych na terenie AKO. }\end{array}$ & 3355000.00 \\
\hline $\begin{array}{l}\text { 3.2. Education and training } \\
\text { infrastructure development/ } \\
\text { 3.2.Rozwój infrastruktury } \\
\text { edukacyjnej i szkoleniowej.. }\end{array}$ & $\begin{array}{l}\text { Investments in the infrastructure of schools and educational establishments } \\
\text { which provide vocational education for youth and adults./ } \\
\text { Inwestycje w infrastrukturę szkół i placówek oświatowych, które prowadzą } \\
\text { kształcenie zawodowe młodzieży i dorosłych. }\end{array}$ & 5000000.00 \\
\hline $\begin{array}{l}\text { 4.1. Implementation } \\
\text { of information and } \\
\text { communication technologies } \\
\text { in order to broaden the } \\
\text { application of e-services./ } \\
\text { 4.1. Wdrażanie technologii } \\
\text { komunikacyjno- } \\
\text { informacyjnych dla } \\
\text { rozszerzenia stosowania } \\
\text { e-usług. }\end{array}$ & $\begin{array}{l}\text { Development of communication and information infrastructure, i.e. an } \\
\text { integrated data distribution tool related to the following areas: environment, } \\
\text { spatial infrastructure, health, business, sports and tourism, education, } \\
\text { culture and art, vocational training, safety and emergency management, as } \\
\text { well as customer service./ } \\
\text { Budowa infrastruktury komunikacyjno-informacyjnej, tj. narzędzie dystry- } \\
\text { bucji zintegrowanych danych z zakresu: środowiska, infrastruktury prze- } \\
\text { strzennej, zdrowia, przedsiębiorczości, sportu i turystyki, edukacji, kultury } \\
\text { i sztuki, szkoleń zawodowych, bezpieczeństwa i zarządzania kryzysowego } \\
\text { oraz obsługi klienta. }\end{array}$ & 1820000.00 \\
\hline $\begin{array}{l}\text { 4.2. Development of cultural } \\
\text { institutions and national } \\
\text { heritage protection./ } \\
\text { 4.2. Rozwój instytucji kultury } \\
\text { i ochrona dziedzictwa } \\
\text { narodowego. }\end{array}$ & $\begin{array}{l}\text { Investments in the protection cultural heritage and development in the } \\
\text { field of, among others: protection of monuments and cultural heritage sites } \\
\text { against deterioration, theft and damage. / } \\
\text { Inwestycje w obszarze ochrony dóbr kultury i rozwoju w zakresie m.in.: za- } \\
\text { bezpieczenia zabytków i obiektów dziedzictwa kulturowego przed degrada- } \\
\text { cją, kradzieżą i zniszczeniem. }\end{array}$ & 3500000.00 \\
\hline $\begin{array}{l}\text { 4.3. Urban and rural areas } \\
\text { revitalisation/ } \\
\text { 4.3.Rewitalizacja obszarów } \\
\text { miejskich i wiejskich. }\end{array}$ & $\begin{array}{l}\text { Restoring the socio-economic function of degraded urban areas belonging } \\
\text { to KOA (including revitalisation of cities and their districts, rural, post- } \\
\text { industrial and post-military areas)./ } \\
\text { Przywracanie funkcji społeczno-gospodarczych zdegradowanych obszarów } \\
\text { miejskich AKO (w tym: rewitalizacja miast i ich dzielnic, terenów wiejskich, } \\
\text { poprzemysłowych i powojskowych). }\end{array}$ & 10000000.00 \\
\hline $\begin{array}{l}\text { 4.4. Development of } \\
\text { water supply and sewage } \\
\text { infrastructure/ } \\
\text { 4.4.Rozwój infrastruktury } \\
\text { wodno-kanalizacyjnej. }\end{array}$ & $\begin{array}{l}\text { Investments contributing to environmental protection (including: } \\
\text { construction, development and renovation of the sanitary sewage system } \\
\text { and municipal wastewater treatment plants)./ } \\
\text { Inwestycje przyczyniające się do ochrony środowiska ( } w \text { tym: budowa, } \\
\text { rozbudowa i remont sieci kanalizacji sanitarnej oraz oczyszczalni ścieków } \\
\text { komunalnych). }\end{array}$ & 3345000.00 \\
\hline $\begin{array}{l}\text { 4.5. Development of road } \\
\text { infrastructure/ } \\
\text { 4.5. Rozbudowa infrastruktury } \\
\text { drogowej. }\end{array}$ & $\begin{array}{l}\text { Expansion of the } 450 \text { provincial road from the "Turnpike" to the border the } \\
\text { city of Kalisz"./ } \\
\text { Rozbudowa ulic w ciągu drogi wojewódzkiej nr } 450 \text { na odcinku od "Rogatki" } \\
\text { do granicy miasta Kalisza”. }\end{array}$ & 6650000.00 \\
\hline
\end{tabular}

Source: Own study based on the data contained in the Integrated Territorial Investment Strategy for the development of the Kalisz-Ostrów Agglomeration 2016.

Źródło: Opracowanie własne na podstawie danych zawartych w Strategii Zintegrowanych Inwestycji Terytorialnych dla rozwoju Aglomeracji Kalisko-Ostrowskiej 2016.

First calls for proposals under the KOA ITI Strategy were announced in the second quarter of 2016, with regard to measures:

- 1.1. Self-employment and creation of new workplaces,

-3.1. Ensuring equal access to high-quality education.

-3.2. Education and training infrastructure development.

The selection of the winning proposal has been scheduled for the first quarter of 2017. ${ }^{6}$.

The above-mentioned scopes of measures become part of the implementation of cohesion policy 20142020 in a manner of postulates. The following factors may affect their actual implementation:

The adopted level of ESF financing, amounting to $85 \%$ of eligible costs, and the maximum total

\footnotetext{
${ }^{6}$ http://sako-info.pl/ogloszenia-naborow. (accessed: 29/08/2016).
}

W ramach Strategii ZIT AKO w II kwartale 2016 r. zostały ogłoszone pierwsze konkursy w ramach działań:

- 1.1. Samozatrudnienie oraz tworzenie nowych miejsc,

- 3.1. Zapewnienie równego dostępu do dobrej jakości edukacji,

- 3.2. Rozwój infrastruktury edukacyjnej i szkoleniowej.

Terminy ich rozstrzygnięć zostały zaplanowane na I kwartał 2017 r. ${ }^{6}$.

Powyższe zakresy działań wpisują się w sposób postulatywny w realizację polityki spójności 2014 2020. Czynnikami, które mogą wpłynąć na faktyczną ich realizację jest:

Przyjęty poziom dofinansowania z EFS w wysokości 85\% kosztów kwalifikowanych, a maksymal-

\footnotetext{
${ }^{6}$ http://sako-info.pl/ogloszenia-naborow. (data dostępu: 29.08.2016).
} 
refunding level of eligible expenditure, at the project level, have been set at a maximum of $95 \%$. The resulting threshold of EU funding will necessitate making additional contribution by local government units (LGU) included in ITI $^{7}$ at the level of at least $5 \%$ of eligible costs. It constitutes an important determinant in the situation of maintaining balanced budgets in JSTs. Frequently, in the case of projects co-financed from external funding, reimbursement is based on the principle of reimbursing expenses already incurred (Kornberger-Sokołowska, Zdankiewicz, Cieślak 2010, p.161).

A wide range of entities entitled to submit applications in response to the announced calls for proposals under ITI (local government units, labour market institutions, social economy entities, nongovernmental organizations, among others). This may contribute to the growth of interest of the local community in the outcome of measures concluded under ITI (with the target of familiarisation with the effects of cohesion policy). A good example is the existing large variety of local partnership activities in Poland. Based on past experience, $85 \%$ of partnerships believe they contribute to a real change in their local environment (Knieć 2010, p. 6).

\section{Conclusions}

The direction of measures resulting from the 2014-2020 cohesion policy principles implemented under ITI addresses actual development problems of the area covered by the KOA strategy as the use of the EU funds under the KOA ITI strategy was in fact planned to: promote entrepreneurship; promote lowcarbon strategies; develop an educated society and invest in modern infrastructure for development. The hypothesis at the beginning of this work has thus been positively verified. The solutions to real problems in the areas covered by the ITI strategy, however, will depend on the actual realisation of the established development goals. Therefore, it is necessary to have a synergy among the conditions associated with transformation of the cohesion policy under ITI from the postulated state into the executive one. This synergy pertains both to the quality of human capital and to the amount of financial resources, as well as competences of institutional entities involved in the implementation of the ITI concept. ny poziom dofinansowania całkowitego wydatków kwalifikowanych na poziomie projektu został ustalony na poziomie maksymalnym 95\%. Wynikający z powyższych limitów próg finansowania unijnego oznacza konieczność poniesienia przez JST wchodzące w skład ZIT wkładu własnego ${ }^{7}$ co najmniej na poziomie 5\% kosztów kwalifikowanych. Jest to istotny wyznacznik w sytuacji utrzymania równowagi budżetowej JST. Nierzadko bowiem w przypadku projektów współfinansowanych ze środków zewnętrznych zwrot środków następuje na zasadzie refundacji poniesionych już wydatków (KornbergerSokołowska, Zdankiewicz, Cieślak 2010, s.161 ).

Szeroki zakres podmiotów uprawnionych do składania wniosków w odpowiedzi na ogłoszone konkursy w ramach ZIT (m.in.: jednostki samorządu terytorialnego, instytucje rynku pracy, podmioty ekonomii społecznej, organizacje pozarządowe). Może to przyczynić się do wzrostu zainteresowania społeczności lokalnych efektami działań uzyskanych w ramach ZIT (docelowo przybliżenia efektów polityki spójności). Dobrym przykładem może być tutaj dotychczasowa duża różnorodność działalności partnerstw lokalnych w Polsce. W oparciu o dotychczasowe doświadczenia 85\% partnerstw uważa, że przyczynia się do realnych zmian w swym środowisku lokalnym (Knieć 2010, s. 6).

\section{Podsumowanie}

Kierunek działań wynikających z założeń polityki spójności 2014 - 2020 implementowanych w strategii ZIT odpowiada na rzeczywiste problemy rozwoju obszaru objętego strategią AKO. Środki unijne w ramach ZIT AKO zostały bowiem zaplanowane na: wspieranie przedsiębiorczości; promocję strategii niskoemisyjnych; rozwój wykształconego społeczeństwa oraz inwestycje w nowoczesną infrastrukturę służącą rozwojowi. Postawiona na wstępie hipoteza została zatem zweryfikowana pozytywnie. Rzeczywiste jednak rozwiązywanie problemów obszarów objętych strategią ZIT zależeć będzie od faktycznego wykonania postawionych celów rozwojowych. Konieczna jest zatem synergia uwarunkowań związanych z przekształceniem stanu postulatywnego $\mathrm{w}$ stan wykonawczy polityki spójności $\mathrm{w}$ ramach ZIT. Synergia ta dotyczy zarówno jakości kapitału ludzkiego jak i wysokości zasobów finansowych oraz kompetencji podmiotów instytucjonalnych zaangażowanych w realizację koncepcji ZIT.

\footnotetext{
${ }^{7}$ Proprietary contribution to projects:

- should be verified in the annual report,

- obligation to make this contribution should be determined in a consultation/cooperation agreement,

- providing one's own contribution rests on the grant recipient or the grant recipient and other local government units constituting a ITI Association. http://www. subregioncentralny.pl/materialy/_upload/prezentacje/ Finanse_ITI.pdf. (accessed: 08/01/2017).
}

${ }^{7}$ Wkład własny w projektach:

- powinien być weryfikowany w sprawozdaniu rocznym, - obowiązek jego poniesienia powinien zostać określony w porozumieniu/umowie o współpracy,

- zapewnienie jego jest po stronie dotacjobiorcy lub dotacjobiorcy i pozostałych JST wchodzących w skład Związku ZIT. http://www.subregioncentralny.pl/materialy/_upload/prezentacje/Finanse_ZIT.pdf. (data dostępu: 08.01.2017). 


\section{References/ Literatura:}

1. Barca F. (2009), An agenda for a reformed cohesion policy. A place-based approach to meeting European Union challenges and expectations. Independent report prepared at the request of Danuta Hübner, Commissioner for Regional Policy, April.

2. Boni M. (2009), (red.) Polska 2030. Wyzwania rozwojowe. KPRM, Warszawa.

3. Boni M.(2013), (red.) Długookresowa Strategia Rozwoju Kraju. Polska 2030. Trzecia fala nowoczesności. MAC (Ministerstwo Administracji i Cyfryzacji), Warszawa.

4. Czapiński J., Panek T. (2013), (red.) Diagnoza społeczna 2013. Rada Monitoringu Społecznego, Warszawa.

5. Dawydzik A. (2015), Polityka Regionalna - Zintegrowane Inwestycje Terytorialne. Ministerstwo Infrastruktury i Rozwoju, Rzeszów, s. 4.

6. De Dominicis L. (2014), Inequality and Growth in European Regions: Towards a Place-based approach. "Spatial Economic Analysis", No 2, s. 120 - 141.

7. Ederveen S., de Groot H.L.F., Nahuis R. (2006), Fertile soil for Structural Funds? A panel data analysis of the conditional effectiveness of European Cohesion Policy. "Kyklos", 2006 No 1, s. 17 - 42.

8. Europa 2020 (2010), Strategia na rzecz inteligentnego i zrównoważonego rozwoju sprzyjającego włączeniu społecznemu, Bruksela, KE.

9. Geodecki T., Gorzelak G., Górniak J., Hausner J., Mazur S., Szlachta J., Zaleski J. (2012), Kurs na innowacje. Jak wyprowadzić Polskę z rozwojowego dryfu? Fundacja GAP, Kraków.

10. Gorzelak G. (2007), (red.) Polska regionalna i lokalna w świetle badań EUROREG-u. Wyd. Naukowe Scholar, Warszawa.

11. Guide to cost-benefit Analysis of Investment projects. Economic appraisal tool for Cohesion Policy 2014-2020, EC Brussesl 2015 b, p. $67-75$.

12. Gwizda M., Kosewska-Kwaśny M., Żółciński Sz. (2014), (red.) Fundusze UE 2014-2020. C.H. Beck, Warszawa, s. 99.

13. Kirkpatrick D.L. (1994), Evaluating Training Programs. Berrett-Koehler Publishers, Inc., San Francisco 1994.

14. Knieć W. (2010), Partnerstwa lokalne w Polsce - kondycja, struktura, wyzwania. Raport badawczy. Fundacja Partnerstwo dla Środowiska, Kraków - Toruń, s. 6.

15. Koncepcja Przestrzennego Zagospodarowania Kraju 2030 (2012), Ministerstwo Rozwoju Regionalnego, Warszawa s. 191.

16. Kornberger-Sokołowska E., Zdankiewicz J., Cieślak R. (2010), Jednostki samorzq̨du terytorialnego jako beneficjenci środków europejskich. Wydawnictwo Wolters Kluwer, Warszawa, s. 161.

17. Misiąg J., Misiąg W., Tomalak M. (2013), Ocena efektywności wykorzystania pomocy finansowej Unii Europejskiej jako instrumentu polityki spójności społeczno-gospodarczej oraz poprawy warunków życia. Wyższa Szkoła Informatyki i Zarządzania, Rzeszów.

18. Olbrycht J., Grosse G. T., Kozak M., Kuźnik F., Palmen L., Sapała M., Woźniak J. (2013), Wyzwania polityki spójności w Polsce 2014-2020 - opinie ekspertów. Wyd. „Wokół nas”, Gliwice.

19. Phillips J.J., Stone R.D., Phillips P.P. (2003), Ocena efektywności w zarządzaniu zasobami ludzkimi. Praktyczny podręcznik pomiaru rentowności inwestycji, Human Factor, Kraków.

20. Wielkopolski Regionalny Program Operacyjny na lata 2014-2020 (2015), Zarząd Województwa Wielkopolskiego, Poznań.

21. Rodriguez-Pose A., Fratesi U. (2004), Między rozwojem a politykq społecznq - europejskie fundusze strukturalne w regionach Celu 1. „Studia Regionalne i Lokalne”, 2004 nr 3 (17), s. 5-32.

22. Samecki P. (2009), Orientation paper on the future of Cohesion policy. EC, Brussels 2009.

23. Sapir A. (2003), An Agenda for a Growing Europe. Making the EU Economic System Deliver. EC, Brussels.

24. Strategia Zintegrowanych Inwestycji Terytorialnych dla rozwoju Aglomeracji Kalisko - Ostrowskiej. Załącznik do uchwały Nr 3/2016 Rady Aglomeracji Kalisko-Ostrowskiej z dnia 20 kwietnia 2016 r., s. 135 - 136.

25. Śleszyński P. (2013), Delimitacja Miejskich Obszarów Funkcjonalnych stolic województw. Przegląd Geograficzny 2013, 85, s. $182-183$.

26. Wiśniewska J. (2014), Rola funduszy strukturalnych w kształtowaniu polityki regionalnej Unii Europejskiej w latach $2007-2013$. W: M. Sikora-Gaca, U. Kosowska (red.), Fundusze europejskie w teorii i praktyce: edukacja, gospodarka, kultura, społeczeństwo. Difin, Warszawa, s. 31.

27. Zasady realizacji Zintegrowanych Inwestycji Terytorialnych w Polsce (2013), Ministerstwo Rozwoju Regionalnego, Warszawa, s. 4.

28. Zintegrowane Inwestycje Terytorialne w Polsce. Ministerstwo Infrastruktury i Rozwoju (2015), Warszawa, s. 4, 11, 29.

\section{Websites/ Strony internetowe:}

29. https://www.funduszeeuropejskie.gov.pl/strony/o-funduszach/zasady-dzialania-funduszy/zintegrowane-inwestycje-terytorialne (data dostępu: 01.08.2016).

30. http://sako-info.pl/ogloszenia-naborow/ (data dostępu: 29.08.2016).

31. http://www.subregioncentralny.pl/materialy/_upload/prezentacje/Finanse_ZIT.pdf./ (data dostępu: 08.01.2017). 